\title{
Performance, Carcass Production, and Meat Quality of Sumba Ongole Bulls Fed Ration Supplemented Velvet Bean (Mucuna pruriens)
}

\author{
S. M. Yantika ${ }^{a}$, Alamsyari $^{a}$, D. Evvyernie ${ }^{b, *}$, D. Diapari ${ }^{b}$, \& K. Winaga ${ }^{c}$ \\ aStudy Program of Nutrition and Feed Science, Faculty of Animal Science, Graduate School, \\ Bogor Agricultural University \\ ${ }^{\mathrm{b}}$ Department of Nutrition and Feed Technology, Faculty of Animal Science, Bogor Agricultural University \\ Jalan Agatis, Kampus IPB Darmaga Bogor 16680, Indonesia \\ cPT. Karya Anugerah Rumpin \\ Jalan Raya Cibodas No. 99 RT 06 / RW 05, Rumpin, Jawa Barat, Indonesia \\ (Received 13-02-2015; Reviewed 17-03-2015; Accepted 04-10-2015)
}

\begin{abstract}
This research aimed to study performance, carcass production, meat quality, and economic feasibility of male Sumba Ongole cattle fed ration supplemented with velvet bean (M. pruriens). The research was designed in a completely randomized block design using 16 cattle with average body weight of $488 \pm 37.08 \mathrm{~kg}$. The treatments were: $\mathrm{T} 0=15 \%$ straw $+85 \%$ concentrate; $\mathrm{T} 1=\mathrm{T} 0+12 \%$ of velvet bean flour supplement; $\mathrm{T} 2=\mathrm{T} 0+16 \%$ of velvet bean tempeh supplement; and $\mathrm{T} 3=\mathrm{T} 0+200 \mathrm{mg} / \mathrm{head} / \mathrm{d}$ of ractopamine hydrocloride. Data were analyzed by using analysis of variance with orthogonal contrast. The observed variables included feed consumption, average daily body weight gain (ADG), feed efficiency (FE), income over feed cost (IOFC), hot carcass weight (HCW), carcass percentage, subcutaneous fat thickness, meat $\mathrm{pH}$, tenderness, cooking loss, and water holding capacity (WHC). The result revealed that the addition of $12 \%$ velvet bean flour into the rations increased dry matter consumption $(\mathrm{P}<0.05)$, but did not affect ADG, FE, IOFC, carcass production, and meat quality. The addition of $12 \%$ velvet bean flour produced the lowest cooking loss $(\mathrm{P}<0.05)$. The addition of $16 \%$ velvet bean tempeh into the rations significantly increased $(\mathrm{P}<0.05)$ dry matter consumption, however reduced $(\mathrm{P}<0.05)$ ADG, $F$, and IOFC compared to control treatment. It is concluded that velvet bean flour at the level of $12 \%$ can be used as an alternative feed supplement in the ration of Sumba Ongole cattle and can replace the use of synthetic ß-agonist.
\end{abstract}

Key words: Mucuna pruriens, Sumba Ongole cattle, performance, carcass, meat quality

\section{ABSTRAK}

Penelitian ini bertujuan untuk mempelajari performa, produksi karkas, kualitas daging, dan economic feasibility dari sapi sumba ongole jantan yang mengkonsumsi kara benguk (M. pruriens). Penelitian ini dilaksanakan berdasarkan rancangan acak kelompok dengan menggunakan 16 ekor sumba ongole jantan dengan rataan bobot badan $488 \pm 37,08 \mathrm{~kg}$ dan menggunakan 4 jenis perlakuan, yaitu: $\mathrm{T} 0=15 \%$ jerami padi $+85 \%$ konsentrat, $\mathrm{T} 1=\mathrm{T} 0+12 \%$ tepung kara benguk, $\mathrm{T} 2=\mathrm{T} 0+16 \%$ tempe kara benguk, dan T3= T0 $+200 \mathrm{mg} / \mathrm{ekor} / \mathrm{hari}$ ractopamine HCl. Data dianalisis menggunakan analisis ragam dan kontras ortogonal. Peubah yang diukur adalah konsumsi ransum, pertambahan bobot badan harian (PBBH), efisiensi pakan (EP), income over feed cost (IOFC), bobot karkas panas, persentase karkas, tebal lemak (subcutan), pH daging, keempukan, susut masak, dan daya ikat air. Hasil penelitian menunjukkan bahwa penambahan $12 \%$ tepung kara benguk meningkatkan konsumsi bahan kering $(\mathrm{P}<0.05)$, namun demikian tidak berpengaruh terhadap $\mathrm{PBBH}$, efisiensi pakan, IOFC, produksi karkas, dan kualitas daging, serta menghasilkan susut masak terendah $(P<0,05)$. Penambahan $16 \%$ tempe kara benguk pada ransum nyata meningkatkan konsumsi bahan kering $(\mathrm{P}<0.05)$, namun demikian menurunkan $(\mathrm{P}<0.05) \mathrm{PBBH}$, efisiensi pakan, dan IOFC dibandingkan kontrol. Dapat disimpulkan bahwa 12\% tepung kara benguk dapat digunakan sebagai pakan tambahan alternatif dalam ransum ternak sumba ongole dan sebagai pengganti $\beta$-agonist sintetis.

Kata kunci: Mucuna pruriens, sumba ongole, performa, karkas, kualitas daging

${ }^{*}$ Corresponding author:

E-mail: erniedea8492@gmail.com 


\section{INTRODUCTION}

The attempts to improve cattle performances have been conducted to maximize unit production per head. For instance, addition of growth inducer, including $\beta$-agonist, has been done to address this issue. Despite the effect is promising, this treatment yielded chemical residues that may harmful for the consumers. Clinical test in European countries revealed that 2 drops of $0.006 \% \beta$-agonist (known as clenbuterol) promoted decreasing of bronchus resistance on asthma patient (Menard, 1994). For similar reasons, some countries had considered that addition of clenbuterol onto the feed as an illegal farming practice. Besides, the practice also promoted the use of compound without control. Recently, toxicity of meat and liver containing clenbuterol was reported in Spain (125 cases) and France (22 cases). The clenbuterol poisoning were characterized by palpitation, tachycardia, dizziness, nervousness, headaches, tremors, and muscle pains (Menard, 1994). For this reasons, the attempts to find substitution of clenbuterol is unavoidable.

Mucuna pruriens, a tropical legume native to Africa and tropical Asia and known as kara benguk in Indonesia, has been widely known as medicinal herb. This plant might, yet need to be confirmed, contain mucunan, serotonin, and L-Dopa (L-3,4-dihydroxyphenilalanine). The presence of L-dopa promotes velvet bean as a promising agent to induce the growth of beef cattle. L-Dopa is known as a precursor for dopamine, a catecholamine hormone. Naturally, L-dopamine is produced by some legumes, especially velvet bean, where it constitutes 5.38\%-6.98\% (Kalidass \& Mohan, 2011). L-dopa, as well as L-phenylalanine and L-tyrosine, is converted to dopamine in central nervous system. L-tyrosine is the first check point for complete synthesis of catecholamine. L-tyrosine is hydroxylated to form dihydroxy-L-phenilalanine (known also as levodopa or L-dopa) by tyrosinase. In respect to dopaminergic neuron, L-dopa is metabolized to dopamine by dopa decarboxylase. Meanwhile, in noradrenergic neuron cells and adrenal medulla, dopamine is transformed to noradrenalin via dopamine $\beta$-hydroxylase. Noradrenaline can be converted to adrenaline by addition of methyl group by phenyl-ethanolamine-N-methyltransferase (Broadley, 2010).

Epinephrine and norepinephrine, physiologically, are known as $\beta$-agonist. There are three types of $\beta$-adrenergic receptor ( $\beta \mathrm{AR})$ have so far been identified, including $\beta_{1^{\prime}}, \beta_{2}$, and $\beta_{3}$ across various organisms with $40 \%-50 \%$ sequence similarities. Dopamine and norepinephrine are produced in hypothalamus and brain to support pituitary gland production and release of growth hormone. In human, the production of this hormone is decrease with the advance of age hence slow down the metabolism process that further yielded degenerative diseases. Study by Imbs \& Schwartz (2011) in mice revealed that after an hour injection of L-dopa, the highest concentration of amino acid was detected in muscle and kept stable even after $4 \mathrm{~h}$. Re-injection of L-dopa had no effect on decreasing of S-adenosylmethionine concentration in muscle and did not cause accumulation of dopamine concentration in the muscle. It indicated that amino acids were not metabolized but kept in muscle at high concentration. This result also indicated that injection of L-Dopa to mice significantly triggered increasing of muscle mass due to the accumulation of protein; it was not by accumulation of fat.

Chikagwa-Malunga et al. (2008) showed that addition of velvet bean at the level of $5-15 \mathrm{~kg} / \mathrm{body}$ weight in Palibuey sheep improved dry matter consumption and body weight linearly. Velvet bean extract as an additive feed can be used up to about $4 \%$ of total ration, meanwhile fermented kara benguk (known as tempeh velvet bean) can be used up to $16 \%$ of total ration. The amount of velvet bean and tempeh velvet bean might support growth and activity of rumen microbes in vitro and improve concentrations of $\mathrm{N}-\mathrm{NH}_{3}$ and VFA and dry and organic matters digestibility (in vitro).

This research aimed to study performance, carcass and meat quality, and economic feasibility of male Sumba Ongole cattle treated with velvet bean (M. pruriens). The use of velvet bean for this purpose is part of attempts in searching of better replacer of $\beta$-agonist in improving cattle performance in related to beef cattle fattening.

\section{MATERIALS AND METHODS}

Seed flour and tempeh velvet bean were manufactured at Laboratory of Dairy Cattle Nutrition, Faculty of Animal Science, Bogor Agricultural University. In vivo testing on cattle was performed in PT Karya Anugerah Rumpin.

The cattle used in this study were male Sumba Ongole cattle at finisher phase. Sixteen cattle were used with average body weights of $488 \pm 37 \mathrm{~kg}$. Ration used in this study consisted of forage and concentrate with ratio of $15 \%: 85 \%$. The concentrate used consisted of molasses, palm kernel, rice bran, gaplek (dried root cassava), copra, onggok (tapioca wastes), corn gluten feed, fish meal, soybean meal, and corn (Table 1). There were four treatments in this study, including control, natural growth promoter in form of kara benguk flour or tempeh and ractopamine $\mathrm{HCl}$ as a positive control. Water and feed were available ad libitum, in which feed was given twice at 9 am and $2 \mathrm{pm}$.

Randomized complete design was used in this study consisting of 4 treatments and 4 cattle as replication, in which each replication used one cattle. The grouping was based on body weight yielding groups of small (424-445 kg), medium $(460-473 \mathrm{~kg})$, large (484$491 \mathrm{~kg})$, and extra-large $(523-551 \mathrm{~kg})$. Meanwhile, ration treatments were:

$\mathrm{T} 0=15 \%$ straw $+85 \%$ concentrate

$\mathrm{T} 1=\mathrm{T} 0+12 \%$ of velvet bean flour supplement ${ }^{*}$

$\mathrm{T} 2=\mathrm{T} 0+16 \%$ of velvet bean tempeh supplement

$\mathrm{T} 3=\mathrm{T} 0+200 \mathrm{mg} / \mathrm{head} / \mathrm{d}$ of ractopamine hydrocloride.

*Adjustment of velvet bean extract dosage to the seed flour: A: 350g; B: 325g; C: $320 \mathrm{~g}$

This study was conducted for $35 \mathrm{~d}$ before the slaughtering process. The variables measured were feed consumption, average daily weight gain (ADG), feed 
Table 1. Composition and nutrient content of the experimental ration

\begin{tabular}{|c|c|c|c|c|}
\hline \multirow{2}{*}{ Item } & \multicolumn{4}{|c|}{ Treatments } \\
\hline & T0 & $\mathrm{T} 1$ & $\mathrm{~T} 2$ & T3 \\
\hline \multicolumn{5}{|l|}{ Ingredients, \% DM } \\
\hline Molasses & 12.00 & 10.71 & 10.34 & 12.00 \\
\hline Palm kernel meal & 4.00 & 3.57 & 3.45 & 4.00 \\
\hline Rice bran & 5.00 & 4.46 & 4.31 & 5.00 \\
\hline Dried cassava & 7.70 & 6.88 & 6.64 & 7.70 \\
\hline Copra meal & 8.00 & 7.14 & 6.90 & 8.00 \\
\hline Tapioca waste & 38.80 & 34.61 & 33.41 & 38.80 \\
\hline Corn gluten feed & 5.00 & 4.46 & 4.31 & 5.00 \\
\hline Fish meal & 4.00 & 3.57 & 3.45 & 4.00 \\
\hline Soybean meal & 3.00 & 2.68 & 2.59 & 3.00 \\
\hline Corn & 6.00 & 5.36 & 5.17 & 6.00 \\
\hline Potato flour & 3.30 & 2.59 & 2.84 & 3.30 \\
\hline Sodium bicarbonate & 0.50 & 0.445 & 0.43 & 0.50 \\
\hline Monensin & 0.007 & 0.006 & 0.006 & 0.007 \\
\hline Salt & 0.20 & 0.18 & 0.17 & 0.20 \\
\hline Limestone & 1.00 & 0.89 & 0.86 & 1.00 \\
\hline Premix $^{1}$ & 0.13 & 0.12 & 0.11 & 0.13 \\
\hline Urea & 1.40 & 1.25 & 1.20 & 1.40 \\
\hline Velvet bean flour & - & 10.71 & - & - \\
\hline Velvet bean tempeh & - & - & 13.79 & - \\
\hline Ractopamine HCL & - & - & - & 0.02 \\
\hline \multicolumn{5}{|l|}{ Nutrient level, \% DM ${ }^{2}$} \\
\hline Dry matter & 87.84 & 88.35 & 87.81 & 87.84 \\
\hline Crude protein & 15.39 & 15.82 & 16.15 & 15.39 \\
\hline Ether extract & 4.01 & 3.87 & 4.53 & 4.01 \\
\hline Crude fiber & 14.21 & 12.78 & 14.16 & 14.21 \\
\hline TDN & 70.22 & 70.51 & 70.60 & 70.22 \\
\hline
\end{tabular}

${ }^{1}$ on $1 \mathrm{~kg}$ Premix consisted of vitamin A, 2000000 IU; Vitamin D3, 400000 IU; Vitamin E, 1200 mg; Ca, 180000 mg; Mg, 5000 mg; P, 10000 mg; Co, $10 \mathrm{mg}$; Cu, $1000 \mathrm{mg}$; I, 15 mg; Fe, 5000 mg; Mn, 6000 mg; Se, 20 mg; Zn, 5000 mg; Antioxidant, q.s mg; Carier, q.s mg.

${ }^{2}$ Laboratory Analysis, Pusat Penelitian Sumber Daya Hayati dan Bioteknologi (2013).

$\mathrm{T} 0=15 \%$ straw $+85 \%$ concentrate (control); $\mathrm{T} 1=\mathrm{T} 0+12 \%$ of velvet bean flour supplement; $\mathrm{T} 2=\mathrm{T} 0+16 \%$ of velvet bean tempeh supplement; and $\mathrm{T} 3=\mathrm{T} 0+200 \mathrm{mg} / \mathrm{head} / \mathrm{d}$ of ractopamine hydrocloride.

efficiency, and income over feed cost (IOFC), hot carcass weight $(\mathrm{HCW})$, carcass percentage, subcutaneous fat thickness, meat $\mathrm{pH}$, tenderness, cooking loss, and water holding capacity (WHC). Feed consumption was calculated by differences between given and remaining feeds. Daily weight gain was calculated based on the differences between the body weight at the beginning and end of the days divided by number of days (referring to the length of study). Feed efficiency was obtained by dividing ADG $(\mathrm{kg})$ with amount of consumed feed (in dry matter). Meanwhile, IOFC was calculated using the following formula (Bailey et al., 2009).

$\mathrm{IOFC}=(\mathrm{PLW} \times \mathrm{ADG})-\mathrm{DFC}$

IOFC $=$ income over feed cost (IDR/bull/d)

PLW = farm-gate price of live weight bull (IDR/kg)

ADG = average daily gain $(\mathrm{kg})$

$\mathrm{DFC}=$ daily feed cost (IDR/bull)
Carcass are the body parts of cattle that had been cut in order to obtain meat and bone without skin, head, feet, tail, and viscera. HCW was obtained from the weighing of carcasses. Carcass percentage was measured by HCW from cattle live weight. Subcutaneous fat thickness was measured with digital caliper in the longissimus dorsi. Meat $\mathrm{pH}$ was measured with $\mathrm{pH}$ meter, tenderness was measured with warner blatzer shear, cooking loss was measured by calculating the difference in meat weight before and after cooked, and WHC was measured according to Muchenje et al. (2009) method.

\section{Data Analysis}

The data were analyzed by using Analysis of Variance (ANOVA) followed by orthogonal contrast test to find the differences among the treatments.

\section{RESULTS AND DISCUSSION}

\section{Feed Consumption}

Treatments on the concentrate used this study significantly affected feed consumption $(\mathrm{P}<0.05)$. Supplementation of velvet bean flour yielded improvement on dry matter consumption up to $11.22 \mathrm{~kg} /$ head/d (Table 2). Meanwhile, when tempeh velvet bean flour was used, the increase of dry matter intake was $11.74 \mathrm{~kg} / \mathrm{head} / \mathrm{d}$. These values correspond to the increase in dry matter consumption by $9.57 \%$ and $14.65 \%$, respectively, as compared to control cattle. In addition, dry and organic matters digestibilities were high enough ranging from $66.56 \%-71.86 \%$ and $67.45 \%-$ $71.34 \%$, respectively, based on in vitro study. This high digestibility is probably due to the presence of active compounds in velvet bean that further affected the feed consumption. Nevertheless, dry matter consumption in control and treated cattle were relatively low. The values varied as following: 1.92\% (control), 2.04\% (velvet bean flour), 2.25 (tempeh flour), and 1.90\% (ractopamine). According to Kearl (1992), dry matter consumption is generally found to be about $2.8 \%$ in the fattening cattle.

Addition of tempeh kara benguk flour yielded the highest dry matter consumption. The high dry matter consumption is probably due to the improved palatability of the ration supplemented with tempeh flour which has fragrant flavor. This flavor might increase the palatability of the ration hence improve dry matter consumption. Walker et al. (2010) reported that ractopamine treatment to heifer significantly reduced dry matter consumption. This report is in good agreement with our result which revealed that ractopamine did not improve dry matter consumption.

\section{Body Weight Gain}

Treatment effects on the average of daily body weight gain (ADG) were found not to be significant, yet orthogonal contrast test revealed some differences among the treatments. Addition of velvet bean flour did not significantly affect ADG, even though numerically higher by $8.28 \%(\mathrm{P}<0.17)$ as compared to control 
Table 2. Performance and income over feed cost (IOFC) of Ongole cattle under various treatments

\begin{tabular}{lrrrrc}
\hline \multirow{2}{*}{\multicolumn{1}{c}{ Variables }} & \multicolumn{5}{c}{ Treatments } \\
\cline { 2 - 6 } & \multicolumn{1}{c}{ T0 } & T1 & T2 & T3 \\
\hline Initial body weight $(\mathrm{kg})$ & $482.75 \pm 40.19$ & $497.50 \pm 40.67$ & $481.50 \pm 41.46$ & $491.50 \pm 40.75$ \\
Final body weight (kg) & $534.25 \pm 34.86$ & $553.00 \pm 55.22$ & $523.25 \pm 40.84$ & $531.00 \pm 40.95$ \\
Weight gain (kg) & $51.50 \pm 11.03$ & $55.50 \pm 16.82$ & $42.00 \pm 3.46$ & $39.50 \pm 2.52$ \\
Average daily weight gain (kg/head/d) & $1.45 \pm 0.26^{\mathrm{a}}$ & $1.57 \pm 0.43^{\mathrm{a}}$ & $1.18 \pm 0.09^{\mathrm{b}}$ & $1.11 \pm 0.07^{\mathrm{b}}$ \\
Dry matter intake (kg/head/d) & $10.24 \pm 0.41$ & $11.22 \pm 0.13$ & $11.74 \pm 0.09$ & $10.07 \pm 0.28$ \\
Dry matter intake (\%) & $1.92 \pm 0.12^{\mathrm{a}}$ & $2.04 \pm 0.21^{\mathrm{c}}$ & $2.25 \pm 0.19^{\mathrm{c}}$ & $1.90 \pm 0.12^{\mathrm{b}}$ \\
Feed efficiency ratio & $0.141 \pm 0.023^{\mathrm{a}}$ & $0.139 \pm 0.037^{\mathrm{a}}$ & $0.100 \pm 0.007^{\mathrm{b}}$ & $0.111 \pm 0.008^{\mathrm{b}}$ \\
Price of live weight (IDR $\left.\times 10^{5}\right)$ & $19.90 \pm 4.31$ & $22.20 \pm 6.72$ & $16.30 \pm 1.23$ & $15.70 \pm 1.05$ \\
Average dry matter intake (kg) & $10,237.00 \pm 409.41$ & $11,221.00 \pm 127.11$ & $11,740.00 \pm 106.96$ & $10,065.00 \pm 276.28$ \\
Daily feed cost (IDR $\left.\times 10^{5}\right)$ & $7.47 \pm 0.29$ & $8.18 \pm 0.09$ & $8.56 \pm 0.06$ & $7.34 \pm 0.20$ \\
Income over feed cost (IOFC) (IDR x10 $)$ & $3.57 \pm 1.18^{\mathrm{a}}$ & $3.70 \pm 1.94^{\mathrm{a}}$ & $1.88 \pm 0.33^{\mathrm{b}}$ & $2.02 \pm 0.33^{\mathrm{b}}$ \\
\hline
\end{tabular}

Note: Means in the same column with different superscripts differ significantly $(\mathrm{P}<0.05)$. T0= $15 \%$ straw $+85 \%$ concentrate $($ control); $1=\mathrm{T} 0+12 \%$ of velvet bean flour supplement; $\mathrm{T} 2=\mathrm{T} 0+16 \%$ of velvet bean tempeh supplement; and $\mathrm{T} 3=\mathrm{T} 0+200 \mathrm{mg} / \mathrm{head} / \mathrm{d}$ of ractopamine hydrocloride.

(Table 2). Feed supplemented with $4 \%$ of velvet bean extract significantly increased volatile fatty acid (VFA) concentration (in vitro study). High level of VFA implied the increased available energy. The increased of energy productivity in the feed indicated the increased of available energy for cattle metabolism. The high ADG value in the cattle treated with velvet bean flour is might be due to availability of $\mathrm{NH}_{3}$. This assumption is evidenced by the concentration of $\mathrm{N}-\mathrm{NH}_{3}$ at feed with velvet bean extract, which was the highest among the treatments (in vitro study).

The cattle treated with tempeh velvet bean and rectopamine had $18.62 \%$ and $23.45 \%$ lower ADG, respectively, as compared to control. In respect to addition of tempeh velvet bean, low level of ADG is might be due to the production of tyrosinase by Rhyzopus oryzae in the digestive tract that changes L-tyrosine and L-dopa to dopaquinone that is further converted back to melanin (Chávez-Béjar et al., 2012). This result indicated the diversion of feed metabolism pathway, in which the feed was metabolized to be coloring compounds, instead of energy. This pathway diversion did not cause any effect on ADG; meat from the cattle treated with the tempeh has darker color compared to others.

Low ADG value in the cattle treated with rectopamine is probable due to low dry matter consumption. As explained by Gruber et al. (2007), ractopamine treatment on steer had no effect on dry matter consumption yet with significant effect on ADG and feed efficiency, with combination of $\mathrm{TBA} / \mathrm{E}_{2}$ (trenbolone acetate/estradiol benzoate) implant. However, TBA/E2 implant was not used in our present experiment. TBA/E2 implant on cattle, as reported by Walker et al. (2011), yielded 10-50 times higher response on the growth as compared to testosterone, hence this implant was widely used as a testosterone replacer. Walker et al. (2011) explained there were significant differences between cattle with or without the implant, in which cattle with implant displayed a better growth performance. Avendano-Reyes et al. (2006) stated that addition of ractopamine in the fattening cattle was less effective as compared to the use of ß-agonist 2.

\section{Feed Efficiency (FE)}

In this study, it was found that there was no differences in FE among treatments (Table 2). However, orthogonal contrast test yielded differences among the treatments. In this study, FE was in the range of 0.10 0.14 , which was considered to be good values for Sumba Ongole cattle. Orthogonal contrast test revealed that the addition of tempeh kara benguk and ractopamine decreased FE by $28.57 \%$ and $21.43 \%$, respectively, as compared to control. The low level of dry matter consumption in the cattle treated with ractopamine might account for the insignificant changes of FE. Yet, addition of velvet bean flour improved FE that was 20.14\% higher than ractopamine treatment (positive control group). Higher FE value suggests a better efficiency of the cattle in metabolizing the feed. According to Vadivel et al. (2011), low protein digestibility is probably due to L-Dopa oxidation which is conjugated to cysteine and form a bond so called 5-s-cysteinyldopa that promotes protein polymerization.

\section{Income Over Feed Cost (IOFC)}

The result revealed that velvet bean flour, tempeh velvet bean, and ractopamine $\mathrm{HCl}$ did not affect IOFC value (Table 2). However, orthogonal contrast test revealed that there were significant differences between control and velvet bean flour with tempeh velvet bean and ractopamine $\mathrm{HCl}$. Weller (1994) reported that body weight gain was highly correlated to FE under the issue of cattle productivity and ADG directly related to IOFC value.

In respect to the addition of velvet bean, IOFC value was Rp1,325.58/head/d that was higher than that of control. Meanwhile, addition of tempeh velvet bean and ractopamine $\mathrm{HCl}$ deceased IOFC by Rp16,911.75/ head/d and Rp15,525.11/head/d, respectively, as compared to control. High value of IOFC in the addition of velvet bean flour was due to a high ADG value in the cattle treated with this flour. ADG highly affects the income. This result was also supported by the improve- 
ment of body shape (esthetic value) which is better as compared to control hence increasing its selling price. In the treatment of velvet bean flour and ractopamine $\mathrm{HCl}$, esthetic value of the cattle was judged to be 10, which is much higher as compared to that of control cattle (8) with bigger belly.

IOFC value in the cattle treated with tempeh velvet bean was the lowest, which was due to the low ADG $(1.18 \mathrm{~kg} / \mathrm{head} / \mathrm{d})$ and high daily feed costing amounting up to Rp27,697.97 head/d. Low IOFC value in tempeh velvet bean treatment was supported by low FE value (0.100) which explained that high feed consumption did not necessarily in line with feed digestibility. Combination of these factors is believed to promote low IOFC value in the cattle treated with tempeh velvet bean.

Cattle treated with ractopamine $\mathrm{HCl}$ (positive control) had lower IOFC value than the control. The most possible factor causing this evidence was low ADG value $(1.11 \mathrm{~kg} / \mathrm{head} / \mathrm{d})$ and high daily feed costing amounting up to Rp24,760.52 head/d. Low ADG value caused low added value obtained from the cattle. As comparison, study by Prasetiyono et al. (2007) showed that beef cattle treated with straw and addition of rice bran and cassava-urea complex, ad libitum, yielded IOFC value only Rp7,500.00/head/d with ADG 0.85 $\mathrm{kg} / \mathrm{head} / \mathrm{d}$. Mayulu et al. (2009) also reported that Simmental crossed beef cattle fed with ammoniated straw based complete ration yielded highest IOFC value of Rp18,391.00/head/d.

\section{Carcass Production}

The statistical analysis proved that all treatment did not affect hot carcass weight, carcass percentage, and subcutaneous fat thickness (Table 3). It is proved that supplementation with either flour, tempeh, and ractophamine $\mathrm{HCl}$ had no significant effect on the development of the hot carcass weight. The use of ractophamine $\mathrm{HCl}$ against hot carcass weight was not significant compared with the control (Sachtleben et al., 2006).

All treatments did not affect carcass percentage $(\mathrm{P}>0.05)$. Supplementation of flour, tempeh, and ractophamine $\mathrm{HCl}$ produce final weight and hot carcass weight almost equal, so carcass percentage is no different. Generally, carcass percentage has a higher value than research Maggioni (2010) that is equal to $52.69 \%$. Quinn et al. (2008) and Winterholler et al. (2007) reported that the addition ractophamine $\mathrm{HCl}$ not significant on carcass percentage.
Statistical analysis showed that treatment outcomes were not significantly different $(\mathrm{P}>0.05)$. In this study, subcutaneous fat thickness ranged 7.5 to $9.2 \mathrm{~mm}$. Fat thickness are affected by triglycerides activity in cattle, and will be stored in adipose tissue under the skin (subcutan) and abdominal cavity (abdomen) if it excess. Feed consumed affect the activity of triglycerides in cattle (Soeparno, 2005).

\section{Meat Quality}

Soeparno (2005) stated that there are two factors that affect the $\mathrm{pH}$ of the meat that are extrinsic (temperature, humidity, stress, and drugs) and intrinsic factors (species, race, sex, muscle, muscle glycogen and activity of enzymes that affect glycolysis). Statistical analysis showed that the treatment was not significantly different to the $\mathrm{pH}$ of meat $(\mathrm{P}>0.05)$ (Table 4$)$. This proved that the addition of velvet bean flour, velvet bean tempeh, and ractophamine $\mathrm{HCl}$ did not affect the meat $\mathrm{pH}$. This result was supported by Avendano-reyes et al. (2006) stated that $\mathrm{pH}$ of beef treated by ractophamine $\mathrm{HCl}$ was not significant to controls.

Statistical analysis showed that the treatment was not significantly different $(\mathrm{P}>0.05)$ to the tenderness of meat. Giving beta agonis resulted the decrease of protein degradation as much as $27 \%$ that was caused by the reduce of proteolitic activity, and the increase of protein synthesis. Protein synthesis boosting changed the diameter of muscle fibers (hypertrophy) that could affect the tenderness of meat (Carr et al., 2005). The provision of tempeh flour and ractophamine $\mathrm{HCl}$ did not leave a negative effect on tenderness of meat. This result was in line with Quinn et al. (2008) stated that the administra-

Table 4. Meat quality of Ongole cattle under various treatments

\begin{tabular}{lcccc}
\hline \multirow{2}{*}{ Variables } & \multicolumn{4}{c}{ Treatments } \\
\cline { 2 - 5 } & T0 & T1 & T2 & T3 \\
\hline $\mathrm{pH}$ & $6.25 \pm 0.09$ & $6.10 \pm 0.14$ & $6.21 \pm 0.20$ & $6.17 \pm 0.17$ \\
Tenderness & $4.80 \pm 0.36$ & $5.10 \pm 0.92$ & $4.10 \pm 1.05$ & $4.60 \pm 0.80$ \\
$\left(\mathrm{~kg} / \mathrm{cm}^{2}\right)$ & & & & \\
Cooking loss (\%) & $43.38 \pm 1.94^{\mathrm{a}}$ & $34.53 \pm 6.64^{\mathrm{b}}$ & $39.37 \pm 3.19^{\mathrm{a}}$ & $39.21 \pm 3.99^{\mathrm{a}}$ \\
Water holding & $29.37 \pm 1.40$ & $29.62 \pm 2.78$ & $27.15 \pm 1.71$ & $31.35 \pm 3.59$ \\
capacity (\%) & & & & \\
\hline
\end{tabular}

Note: Means in the same column with different superscripts differ significantly $(\mathrm{P}<0.05)$. $\mathrm{T} 0=15 \%$ straw $+85 \%$ concentrate (control); $\mathrm{T} 1=$ $\mathrm{T} 0+12 \%$ of velvet bean flour supplement; $\mathrm{T} 2=\mathrm{T} 0+16 \%$ of velvet bean tempeh supplement; and T3= T0 + $200 \mathrm{mg} / \mathrm{head} / \mathrm{d}$ of ractopamine hydrocloride.

Table 3. Carcass performance of Ongole cattle under various treatments

\begin{tabular}{lrrrr}
\hline \multirow{2}{*}{ Variables } & \multicolumn{4}{c}{ Treatments } \\
\cline { 2 - 5 } & \multicolumn{1}{c}{ T0 } & \multicolumn{1}{c}{ T1 } & \multicolumn{1}{c}{ T2 } \\
\hline Final body weight $(\mathrm{kg})$ & $534.25 \pm 34.88$ & $553.00 \pm 55.21$ & $523.25 \pm 40.84$ & $531.00 \pm 40.94$ \\
Hot carcass weight (kg) & $294.75 \pm 24.19$ & $288.25 \pm 27.63$ & $284.25 \pm 25.66$ & $300.75 \pm 11.53$ \\
Carcass percentage (\%) & $55.24 \pm 4.35$ & $52.24 \pm 3.73$ & $54.29 \pm 1.08$ & $56.79 \pm 2.90$ \\
Subcutaneous fat thickness (mm) & $8.56 \pm 1.05$ & $7.57 \pm 0.56$ & $9.04 \pm 1.48$ & $9.24 \pm 0.09$ \\
\hline
\end{tabular}

Note: Means in the same column with different superscripts differ significantly $(\mathrm{P}<0.05)$. T0= $15 \%$ straw $+85 \%$ concentrate $($ control); $1=\mathrm{T} 0+12 \%$ of velvet bean flour supplement; $\mathrm{T} 2=\mathrm{T} 0+16 \%$ of velvet bean tempeh supplement; and $\mathrm{T} 3=\mathrm{T} 0+200 \mathrm{mg} / \mathrm{head} / \mathrm{d}$ of ractopamine hydrocloride. 
tion of ractophamine $\mathrm{HCl} 200 \mathrm{~g} / \mathrm{head} / \mathrm{d}$ in heifers had no effect on tenderness.

Cooking loss is nutritional value indicator of meat related to the water content of the meat, which is the amount of water that is bound in and between the muscles. Factors affecting the cooking loss including $\mathrm{pH}$, temperature, cooking time, and the type of muscle. Meat having $\mathrm{pH}$ values above 6 has a high cooking loss (Lawrie, 2003). The high value of cooking loss is an indicator of a weakening of protein bonds, so the ability to bind meat fluid weakened. The treatment of velvet bean flour significantly affected cooking loss $(\mathrm{P}<0.05)$. Velvet bean flour supplementation resulted in lower cooking loss compared to control and other treatments. It might be caused by catecholamine contained in velvet bean flour was not fully overhauled after processing. Catecholamine can bind a specific $\beta$-adrenergic receptor in fat tissue and muscle cells so it could decrease gluconeogenesis (Walker \& Drouillard, 2010).

Velvet bean tempeh and ractophamine $\mathrm{HCl}$ to the water holding capacity showed that the results were not significantly different $(\mathrm{P}>0.05)$ (Table 4$)$. The $\mathrm{pH}$ value has a relationship with water holding capacity (WHC), the higher $\mathrm{pH}$ value will result in the higher WHC, also vice versa (Soeparno, 2005). This has been described above that the $\mathrm{pH}$ in this study were not significantly different. Quinn et al. (2008) also stated that ractophamine $\mathrm{HCl}$ usage was not significant to the water binding power.

\section{CONCLUSION}

Velvet bean flour at the level of $12 \%$ increased dry matter consumption, but did not affect ADG, FE, IOFC, carcass production, and meat quality. It could be concluded that $12 \%$ velvet bean flour could be used as an alternative feed supplement in the ration of Sumba Ongole cattle and could replace the use of synthetic ß-agonist.

\section{ACKNOWLEDGEMENT}

This work is supported by grant Bantuan Operasional Perguruan Tinggi Negeri (BOPTN) 2013. Authors would like to express deepest gratitude to PT. Karya Anugerah Rumpin, Rumpin Bogor for providing cattle feedlots for this study.

\section{REFERENCES}

Avendaño-Reyes, L., V. Torres-Rodríguez, F. J. Meraz-Murillo, C. Pérez-Linares, F. Figueroa-Saavedra, \& P. H. Robinson. 2006. Effect of two $\beta$-adrenergic agonists on finishing performance, carcass characteristics and meat quality of feedlot steers. J. Anim. Sci. 84: 3259-3265. http://dx.doi. org/10.2527/jas.2006-173

Bailey, K., T. Beck, E. Cowan, \& V. Ishler. 2009. Dairy Risk Management Education: Managing Income Over Feed Costs. Agricultural Communications and Marketing, The Pennsylvania State University, PA, USA.

Broadley, K. J. 2010. The vascular effects of trace amines and amphetamines. Pharmacol. Therapeut. 125:363-375. http:// dx.doi.org/10.1016/j.pharmthera.2009.11.005
Carr, S. N, D. J. Ivers, D. B. Anderson, D. J. Jones, D. H. Mowrey, M. B. England, J. Killefer, P. J. Rincker, \& F. K. McKeith. 2005. The effects of ractopamine hydrochloride on lean carcass yields and pork quality characteristics. J. Anim. Sci. 83:2886-2893.

Chávez-Béjar, M. I., J. L. Báez-Viveros, A. Martínez, F. Bolívar, \& G. Gosset. 2012. Biotechnological production of 1-tyrosine and derived compounds. Process Biochemist. 47:10171026. http://dx.doi.org/10.1016/j.procbio.2012.04.005

Chikagwa-Malunga, S. K., A. T. Adesogan, M. B. Salawu, N. J. Szabo, R. C. Littell, S. C. Kim, \& S. C. Phatak. 2008. Nutritional characterization of Mucuna pruiriens: 2. In vitro ruminal fluid fermentability of Mucuna pruriens, Mucuna 1-dopa and soybean meal incubated with or without 1dopa. J. Anim. Feed Sci. Technol. 148: 51-67. http://dx.doi. org/10.1016/j.anifeedsci.2008.03.005

Gruber, S. L., J. D. Tatum, T. E. Engle, M. A. Mitchell, S. B. Laudert, A. L. Schroeder, \& W. J. Platter. 2007. Effects of ractopamine supplementation on growth performance and carcass characteristics of feedlot steers differing in biological type. J. Anim. Sci. 85:1809-1815. http://dx.doi. org/10.2527/jas.2006-634

Imbs, J. L. \& J. Schwartz. 2011. Advance In The Biosciences Peripheral Dopaminergic Receptors. Pergamon Press. Vol 20; Pp : 95-99

Kalidass, C. \& V. R. Mohan. 2011. Nutritional and antinutritional composition of itching bean (Mucuna pruriens (1.) Dc var. Pruriens): an underutilized tribal pulse in western ghats, Tamil Nadu. Trop. Subtrop. Agroecosyst. 14: 279293

Kearl, L. C. 1982. Nutrient requirements of ruminants in developing countries. International Feedstuffs Institute. Utah Agricultural Experiment Station. Utah State University, Logan Utah.

Lawrie, R. A. 2003. Ilmu Daging. Terjemahan: A. Parakkasi. Penerbit. Universitas Indonesia Pr., Jakarta.

Maggioni, D., J. A. Marques, P. P. Rotta , D. Perotto,T. Ducatti, J. V. Visentainer, \& I. N. Prado. 2010. Animal performance and meat quality of crossbred young bulls. Livest. Sci. 127:176-182. http://dx.doi.org/10.1016/j.livsci.2009.09.006

Mayulu, H., B. Suryanto, Sunarso, M. Christiyanto, F. I. Ballo, \& Refa'i. 2009. Feasibility of complete feed based on ammoniated fermented rice straw utilization on the beef cattle farming. J. Indonesian Trop. Anim. Agric. 34: 74-80.

Menard, L. 1994. The use of clenbuterol in large animal obstetrics: Manual correction of bovine dystocias. Can. Vet J. 35: 289-292

Prasetiyono, B. W. H. E., Suryahadi, T. Toharmat, \& R. Syarief. 2007. Strategi supplementasi protein ransum sapi potong berbasis jerami dan dedak padi. Med. Pet. 30: 207-217.

Quinn, M. J., C. D. Reinhardt, E. R. Loe, B. E. Depenbusch, M. E. Corrigan, M. L. May, \& J. S. Drouillard. 2008. The effects of ractopamine-hydrogen chloride (optaflexx) on performance, carcass characteristics, and meat quality of finishing feedlot heifers. J. Anim. Sci. 86: 902-908.

Sachtleben, S., E. Thomas, W. J. Platter, \& A. Schroeder. 2006. Evaluation of feeding ractopamine (Optaflexx®) with various levels of dietary crude protein on growth performance in feedlot steers. J. Anim. Sci. 84(Suppl. 1):118. (Abstr.)

Soeparno. 2005. Ilmu dan Teknologi Daging. Gadjah Mada.University press. Yogyakarta.

Vadivel, V., M. Pugalenthi, A. Doss, \& T. Parimelazhagan. 2011. Evaluation of velvet bean meal as an alternative protein ingredient for poultry feed. J. Anim. 5: 67-73. http:// dx.doi.org/10.1017/S175173111000159X

Walker, C. E. \& J. S. Drouillard. 2010. Effects of ractopamine hydrochloride are not confined to mammalian tissue: Evidence for direct effects of ractopamine hydrochloride 
supplementation on fermentation by ruminal microorganisms. J. Anim. Sci. 88:697-706.

Walker, D. K., E. C. Titgemeyer, T. J. Baxa, K. Y. Chung, D. E. Johnson, S. B. Laudert, \& B. J. Johnson. 2010. Effects of ractopamine and sex on serum metabolites and skeletal muscle gene expression in finishing steers and heifers. J. Anim. Sci. 88: 1349-1357. http://dx.doi.org/10.2527/ jas.2009-2409

Walker, D. K., E. C. Titgemeyer, D. E. Johnson, S. B. Laudert, \& B. J. Johnson. 2011. Effects of ractopamine and gender on protein turnover in skeletal muscle of implanted steers and heifers. S. Afr. J. Anim. Sci. 41: 16-23.

Weller, J. I. 1994. Evaluation of Genetic Differences from Profit Equations. In Economic Aspects of Animal Breeding. Chapman \& Hall, London. Pp 78-90.

Winterholler, S. J., G. L. Parsons, C. D. Reinhardt, J. P. Hutcheson, W. T. Nichols, D. A. Yates, R. S. Swingle, \& B. J. Johnson. 2007. Response to ractopamine-hydrogen chloride is similar in yearling steers across days on feed. J. Anim. Sci. 85:413-419. 